\title{
Remedial Education for Children with ADHD in Sweden
}

\author{
Jane Brodin \\ Stockholm University \\ Sweden
}

\section{Introduction}

The purpose of this chapter is to increase the understanding and knowledge of children with Attention Deficit Hyperactivity Disorder (ADHD) and their everyday lives in educational settings. As these children constitute an ever increasing group all over the world and the disorder really creates huge problems for them in school, this chapter will focus on remedial education in Sweden. In this chapter I will highlight the interdisciplinary research project Basic skills, social interaction and training of the working memory (BASTA) that included vital aspects related to education. Three research teams: one medical and two pedagogical were involved. The pedagogical teams at Stockholm Institute of Education (teacher training university) were responsible for child studies and special education. The tasks for the special education team was to study the basic academic skills and for the child studies the focus was on issues related to children's perspectives of the meaning of being a child with ADHD and on children's school environments. Issues related to education of children with ADHD are based on self-concept, teaching, ethical issues and children's views, as these aspects are important in school. I will also make some recommendations for education.

ADHD is a neuro-psychiatric disorder of childhood that is characterized by developmentally inappropriate levels of hyperactivity, impulsivity and inattentiveness. The prevalence of ADHD in Sweden is estimated to 3 to 6 per cent of all school-age pupils (Ljungberg, 2001; Ljusberg, 2009), and in the US the figures are similar, i.e. 3 to 7 per cent (DuPaul \& White, 2006). Ljungberg (2001) argues that if also Deficit in Attention, Motor Control and Perception (DAMP) is included, the figure would increase to approximately 10 per cent. The disorder occurs more often in males than females with the sex ratio being about 3.4 to 1 . Nevertheless, ADHD is one of the most common psychiatric disorders in childhood (Wells, 2004). The reason for the disorder is according to medical studies a deviation in the brain which leads to behavioural disturbances and social difficulties (Westerberg, 2004). Based on these findings the medical discourse has to a great extent influenced the Swedish educational system as well as the school systems in other countries (Harwood, 2006; Lloyd, 2006).

The number of detected children with ADHD is thus increasing and for these children and people in their immediate environment neuro-psychiatric disorders cause huge problems 
with regard to learning, teaching and social interaction. This has resulted in an increasing demand for special classes in school and we can today note that there are special classes for children with for instance ADHD, Asperger syndrome, dyslexia/reading and writing deficits, speech and language disorders, slow learners and for children with psychosocial problems. This trend is global in spite of the fact that most countries for the time being are promoting inclusion of all children in a school for all (Brodin, 2008; Norwich, 2008).

All children have the right to education, participation and equal opportunities according to the UN Convention on the Rights of the Child (1989) but for these children and their parents everyday life is often a struggle, as ADHD has not always been regarded as a real disorder. Many parents have felt unhappy and misunderstood and they have by people in the environment been regarded as incompetent to raise their children in a proper way (e.g., Hellström, 2004, 2010; Kadesjö, 2010). This has given many parents bad conscious and hard feelings of blame and guilt. This problem is well-known in research and in a guide for parents and professionals Chandler (2010) argues that despite the dramatic increase in the diagnosis and treatment of ADHD the disorder is not new. The topic has been highlighted in a number of reports, e.g. the International Consensus Statement on ADHD (Barkley, 2002). The consensus statement aims at confirming that ADHD is a real and valid disorder and that there is no doubt regarding its existence. Below is a brief summary of the report.

\subsection{International consensus statement on ADHD (2002)}

It appears from the report that ADHD is one of the most researched disorders in medicine. The statement is signed by 86 leading scientists; the majority professors from the medical field. The purpose was to stress the status of the diagnosis and to substantiate that ADHD is a medical condition but it is also a protest against inaccurate, populist stories of ADHD in media that may negatively influence children and adults who suffer from it to require professional help and treatment. The involved scientists realized that there was an obvious risk that thousands of sufferers would not 'seek treatment for their disorder', and added that 'there is no controversy regarding its existence' (p. 89). It appears that ADHD causes impairments in major life activities and that these children are at risk for physical injuries at a larger extent than other children, as they have difficulties to judge the consequences of an action. This is most reasonable a result of the psychological deficits in attention and inhibition. However, ADHD cannot be explained as a medical problem only as the environmental aspects (e.g. family or school setting) are contributing to the neuropsychiatric condition of the child. The social interaction between the genetics and environmental factors are thus a decisive prerequisite, and both are of importance when the most suitable treatment is taken into consideration. The difficulties in everyday life primarily concern domains such as education, social relations, self-esteem, self-concept, family functioning, and independence (p. 90).

Furthermore it appears from the report that it is common that children with ADHD have other associated disorders mainly related to their social environment e.g., communication disorders and emotional disturbances. All these difficulties account for a large number of referrals to pediatricians, family physicians and child mental health professionals but less than half of all persons (primarily children) with ADHD receive treatment. 


\subsection{What do we know about ADHD?}

ADHD is an ever increasing disorder among children especially in the western world and one reason for experiencing an increase is probably that we nowadays have opportunities to detect the disorder easier and have access to instruments to diagnose these children (Chandler, 2010). The disorder has been the focus of a large number of scientific and clinical studies over the last centuries and one of the front figures in Sweden is Gillberg (2005), who early noticed the difficulties the disorder caused children with DAMP and ADHD in school. Based on research he recommended placement in small groups, individual instructions in maths, reading and writing, short intervals of concentration during the first years in school, regular breaks and physical activities. His team also showed that these recommendations functioned in practice and made everyday life easier for the children. These recommendations are in fact supportive for all children, i.e. typical and atypical, but in school the situation often looks different. Too many pupils in each class are obstacles that make individual intervention problematic for the teachers. Consequently, many teachers feel insufficient and think that they are not good enough in their profession. Teachers often state in interviews that they would prefer to teach in another way than they do (Brodin, 2009) but the lack of time and too many pupils in each class is a reality in today's school.

Due to the inattentiveness and difficulties to maintain attention they need breaks and physical activities. The need to use their bodily capacities in combination with their often bully behaviour are challenging for the teachers and quite often the disorder in the classroom is extremely demanding. One way to meet the needs of these children is to be flexible and not necessarily keep to the time schedule and curricula. This might in many countries be controversial as teachers in general are supposed to follow the curricula. However, if a child's learning is the main goal in school this effort would contribute to better opportunities to take charge of the education.

What we really know from research is that ADHD is a disorder that creates many difficulties for the child and his or her family and the harm is noticed by the increased mortality, morbidity and difficulties in everyday life both for children and adults (Alin Åkerman, 2008; Ingvar, 2004; Teeter, 2004).

\subsection{Tools for classification of ADHD}

In order to classify the disorder different tools are used. The Diagnostic and Statistical Manual of Mental Disorders (DSM-IV) from 2000 and the Who's International Classification of Disorder (ICD-10) are the most frequently used tools to classify ADHD and it is evident that difficulties to maintain attention/concentration and hyperactivity/impulsiveness are the most common problems. Three different types of ADHD can be recognized: inattentiveness and hyperactivity mainly inattentiveness (AD), inattentiveness and hyperactivity mainly hyperactivity/impulsivity (HD), and inattentiveness and hyperactivity in combination (ADHD). A majority of the children have a combination of inattentiveness and hyperactivity.

From DSM-IV appears that the symptoms should have been noticed before the child is seven years old and appear within at least two areas (e.g., in school and at home) and to imply a clinical significant disability in daily life. The diagnostic criteria are defined, but still many professionals have difficulties to be sure as the degree of the problems differ in 
different environments and with different people around them. Ljusberg (2010) means that there are also certain situations and tasks in school that cause concentration difficulties. She thus supports Danby and Farrell (2004) who argue that when the school ascribes difficulties to pupils it contradicts its striving for children's agency, competence and participation. Ljusberg's standpoint is thus that the children acquire concentration difficulties in school (2010).

\subsection{Research on children with ADHD}

The majority of studies on children with ADHD focuses on medical, psychological, social and educational aspects. The school situation is often described as problematic. Barkley (1997) argues that the limited capacity to prevent the impulse from immediate action is the core in the ADHD complex of problems. He states that these children act immediately when they get an idea and they do not or cannot consider the consequences. For this reason they are often involved in conflicts with peers, parents and teachers. Many children with ADHD also have low self-esteem and self-confidence and fail in schoolwork (Brodin \& Ljusberg, 2008; Ljusberg \& Brodin, 2007).

The disorder can be defined and explained in many different ways depending on the researcher's perspective and knowledge. Most neurological studies highlight that persons with ADHD have low electrical activity in the brain and show less reactivity to stimulation in one or more regions in the brain (Klingberg et al., 2005). The mounting evidence of neurological and genetic contributions to ADHD is a fact (Barkley, 2002). For this reason treatment with drugs that stimulates the central nervous system e.g., Dopamine, Retalin or similar drugs is often recommended, and this is one reason for critics e.g. from pedagogues and sociologists. Many doctors prescribe drugs to help the child and most researchers in neuro psychiatry in Sweden support medication (Eriksson \& Ingvar, 2004; Kadesjö, 2010) but there has been an intensive debate for and against prescription of drugs for children with ADHD. However, with regard to all the negative consequences these children have to face in everyday life, drugs seem to be a solution for these children and their families. It is however vital to point out, that drugs is never the first and only choice when treatment is considered.

Nevertheless, ADHD leads to impairments in everyday life related to education, social relations and family functioning. The very first step is to look at the immediate environment in school and find out if it is possible to make any changes in the classroom that would facilitate learning and social interaction for these children. The physical environment in school can be adapted to better correspond to the needs of these children. Other factors of importance are teacher training, i.e. that the teachers have a formal teacher education, have high competence in children in need of special support, have knowledge of the difficulties children with ADHD have, and finally how they structure their teaching to make learning optimal. Equal value and consideration must be taken into account for teaching and learning.

From a pedagogical point of view Tannock and Martinussen (2001) stress that ADHD is primarily a cognitive disability, but like most researchers Ljungberg (2001) emphasizes that ADHD can develop differently and it is reasonable to believe that the disorder can be based both on genetic and psychosocial factors, or be a combination of both. Kadesjö (2010) 
stresses the connection between the prevalence of physical and emotional disturbances, and charging social factors. The higher prevalence of physical unhealth in children from socioeconomic disadvantaged families can be explained by an increased prevalence of risk factors. The environmental factors thus affect the disorder - positively or negatively. Beckman and Fernell (2004) state that children with ADHD in school often have short patience, easily loose their temper and 'explode', interrupt their peers in play and school work and have difficulties to wait for their turn, which often results in school problems. They are often involved in conflicts with peers, have difficulties to handle their feelings, to express themselves and often feel frustrated.

The symptoms vary over time and in different environments although the difference between each individual is huge. Functions related to special thinking processes are limited and they have often limitations in the working memory meaning that they have problems to store and process information and impressions. Many difficulties are thus related to the social environment. The mixture of medical, social and educational factors entail that in order to be successful intervention needs to start with observations of the child in his or her natural context.

This chapter is based on the research project BASTA (Basic skills, social interaction and training of the working memory) which was a longitudinal project with focus on children between nine and twelve years with ADHD or similar symptoms. Only 19 out of 41 children involved in the study have been diagnosed with the tools mentioned above, i.e. DSM-IV or ICD-10. Similar symptoms mean that the undiagnosed children were hyperactive, inattentive, bully, disturbing, had behaviour problems, difficulties to accept social rules and were often involved in conflicts. A majority of them had been placed in remedial classes after recommendation of the teacher without asking the child about his or her opinion. This is also an ethical dilemma. Ljusberg (2009) is very critical to these placements and states that the best of the child is not considered. The parents were often relieved as they could now feel that their child was now placed in a class with more help. This does not promote legal rights of the child, and it conflicts with the UN Convention on the Rights of the Child (1989), which Sweden has ratified.

This chapter will focus on the implications of ADHD in children's everyday life and give some ideas of what actions can be taken to facilitate their daily lives and diminish their difficulties. Focus will also be on their social interaction with peers and teachers in school, as children of this age spend most of their daily time in school and with peers. Education is a right for all children and in the following sections I will introduce the Swedish school system and the growing remedial education.

\section{The Swedish school system}

The Swedish Education Act is based on the UN Convention on the Rights of the Child (1989) and stress education and school for all children. Regardless of gender, ethnic background and social or economic factors all children have equal rights to education on equal conditions in a school for all. Another aspect influencing the Swedish school system is the integration endeavours that can be seen as an obvious result of the Normalization Principle (Nirje, 2003) during the 50'ies and 60'ies. Sweden has gradually moved from a differentiation perspective to an integration perspective, i.e. from one that isolates to one 
that includes (Brodin \& Lindstrand, 2007). Also the Salamanca Statement (2001) has enhanced inclusion and an inclusive school. As a result of this most children in Sweden are today attending the municipal school in their immediate environment often located close to their homes. School is free of charge and compulsory for all children between seven and sixteen years of age. Inclusion is a goal and key concept in the Swedish society and thus also in school. This means that all children are expected to attend the regular schools. No rule without exceptions!

The special schools have closed down and a majority of all children in need of special support today attend the regular school but still there are special programmes for instance for children with intellectual disabilities. However, the number of children with neuropsychiatric diagnoses and in need of special support in the Swedish schools is increasing and results in an increasing number of special solutions (Matson, 2007). This means that some children still are excluded and segregated in the Swedish inclusive school. These children are placed in small groups or classes, special classes or remedial classes, depending on what expression you choose to use. I will use remedial classes although the meaning is the same - segregation.

\subsection{Remedial classes}

In the municipality of Stockholm the remedial classes increased from 112 in 1998/99 to 180 seven years later (Ljusberg, 2009), and this is contradictory to school policy and research as few studies support exclusion and no support has been found for the superiority of remedial classes (e.g., Karlsson, 2008; Skidmore, 2004). In Sweden, a diagnosis is not needed for placement in a remedial class which means that the main reason for placement often is behaviour problems and the suggestion to move the child to a remedial class often comes from the teacher. Critical voices are raised against this solution and state that some teachers want to have these children moved in order to facilitate their own work. They have not listened to the child's voice and asked for his or her opinion which is against the UN child convention. Previously the diagnosis was closely connected to economic means to the school from the state, in other words 'no money - no support'. This change is a positive development as support can nowadays be given also to children in need of support but without a diagnosis.

Remedial classes have been a reality in Sweden since the public elementary school was introduced in 1842 (Brodin \& Lindstrand, 2007). The distinction between regular and special education was earlier that the difficulties should be diminished and that the placement in a remedial class should be temporarily. All pupils in need of special support are, based on their needs, entitled to receive support in school, primarily in the class they normally attend. However, this has turned out to be very difficult and a majority of them are on the opposite moved to a remedial class. Few pupils return to their regular classes. The arguments supporting the establishment of remedial classes have in the past century pointed out two main ideas. The first one is to protect the children and support their self-esteem by shielding them from pupils who perform better (ibid.). Another argument concerns the teacher as these children need much time and space and thus have less time to spend on the other pupils in the class. Children with ADHD in remedial classes may develop a negative identity (Ljusberg, 2009) which means 'I'm a child in need of support, I lack competence and I'm not good enough' and if they are labelled and regarded to be children at risk when they 
start school, this view will follow them during their entire school careers (Alin Åkerman, 2008; Brodin, 2008).

The remedial class has high teacher density and the average number of pupils per adult and class varies between two and three. Generally, the number of pupils in the class is five to eight. The instructions are given face-to-face and individually to each child. The self-concept of children with ADHD in remedial classes is influenced by the fact that they as a matter of fact are placed in the remedial class. They know that they have got this placement due to their difficulties and failures in school and that they require special support (Taube et al., 1984). Early school experiences will create a feeling of confidence that will help them to proactively enhance their academic development (Brodin, 1997). One problem is that many pupils receive negative feedback on socially unapproved behaviours from parents and teachers (e.g., Teeter, 2004).

Negative academic experiences may jeopardize the children's immediate and future views of their academic abilities. At the least; the early negative experience may create a sense of doubt that will likely hinder the student's academic performance and motivation (Pisecco et al, 2001, $\mathrm{p}$ 458).

It is reasonable to believe that negative feedback is better than no feedback at all, as the most important for all pupils is to be seen, i.e. to be somebody ('look at me - I'm here'). They often do what they think is the best way in a special context. The self-concept is created in the individual in a social context and as stressed above it is based on biological aspects in relation with the social environment.

\section{The BASTA project}

The BASTA (Basic skills, social interaction and training of the working memory) project was an interdisciplinary project with the overall purpose to explore how training of the working memory with the computer-based programme RoboMemo affected children's basic academic skills and social interaction. The project was based on collaboration between three scientific teams from the medical and pedagogical fields (special education and child studies). The computer-based programme was developed by a research group at Astrid Lindgren's Children's Hospital at the Karolinska Institute (KI) in Stockholm. The responsibility of my team was to focus on child and youth studies, which means that we have the child in the centre and as far as possible try to see things from the perspective of the child in a context.

The main project idea was to get a holistic view of the children involved based on the different perspectives. The sub-studies will be presented at the end of this section, but I will start to give some facts on the working memory as it is central for children's learning and consequently also affects teaching.

\subsection{Working memory}

Working memory research is based to a great extent on neurological findings focused on biological phenomena and presumed genetic defects. The working memory is of great importance for learning and problem-solving and research has shown that it is possible to train the capacity of the working memory (Klingberg et al., 2005; Westerberg, 2004). The 
working memory helps us for instance to remember what we are going to do next which is necessary in school work. The working memory is used when the child is reading and writing, for mathematics, and problem-solving, and this affects their academic achievements. The programme consists of nine different exercises each designed to challenge and improve the working memory capacity from different angles that is both verbal and visuo-spatial. The degree of difficulty is adjusted and will increase continuously in accordance with the child's achievements as the training progresses. The children $(\mathrm{N}=41)$ participated in the training daily during five weeks. Each session was between 30 and 45 minutes and each child involved had an adult (teacher or assistant) aside who was responsible for the training. Criteria for inclusion were average intelligence, deficits in attention with or without the diagnosis ADHD and attending a remedial class in a regular school. Criteria for exclusion were autism, hearing or visual impairments. The children involved were between nine and twelve years of age. Before the children were selected to participate they were interviewed by a psychologist from the project team in order to find out if the child should be included or excluded from involvement in the project.

The interactive computer-based training programme RoboMemo was based on the assumption that the working memory can be improved by training. Research had as mentioned previously showed that significant improvements had been achieved with regard to problem-solving, attention span and impulse control when children with ADHD had been working with the programme (Klingberg et al., 2005). An evaluation of the RoboMemo training programme was conducted in a child habilitation centre in the south of Sweden (Landin, 2007) and the positive results were supported, although the number of participants was very small. Only nine children with ADHD participated in the evaluation. Psychological tests and rating scales showed positive effects. The involved children had improved their working memory capacity and diminished the dysfunction in behaviour but the limited number of participants made it impossible to generalize.

The two research teams at Stockholm Institute of Education (teacher training university) were responsible for child studies and special education. Data have been collected by interviews, questionnaires and classroom observations with children, parents and teachers. Data from 41 children (9-12 yrs old), their parents and 21 teachers in twelve different classes in nine schools have been collected. The special education team conducted studies concerning the basic academic skills in order to find out if and how the training of the working memory affected their skills. They used rating scales and tests and found positive correlations between the training and the performance. The final results of these studies have not yet been published. Four sub-studies were conducted within the field of child and youth studies: self-concept, teaching, ethical issues and children's views. The main reason was to find out if and how the children's self-concept changed after having trained the working memory. Did the improved skills affect their self-concept materially? As we know that these children experience a difficult school day the next focus was on the teacher and the school setting. How is the situation in school for children with ADHD from teacher perspective? What do the parents think about the school situation of their child? Early we noticed that many decisions had been taken 'over the head' of the child and without listening to the child's voice and this resulted in the third study on ethical issues. The forth sub-study focused on how these children thought about their everyday life with special focus on school, which is the arena children attend daily. Together all four sub-studies give 
a contribution to a greater understanding of children with ADHD and how they think, and hopefully this may diminish school failures. How can peers and adults in the immediate environment support these children in order to increase their well-being? The results of these four sub-studies will be included under the headings below. The concepts children and pupils are used synonymously in the text.

\section{Self-concept in children with ADHD}

Children's creation of identity is based on interaction between what they think about themselves as human beings and on the image they receive from the context, i.e. what other persons think about them (Brodin, 1997). The self-concept can be negative or positive depending on the social environment and therefore this study has a socio-cultural approach. Research on self-concept in children with ADHD is limited and two different lines are visible. Some researchers argue that these children have a low self-concept but they report a higher self-concept than expected (e.g., Hoza et al, 2002). Other researchers argue that they have low self-concept and poor self-esteem (e.g., Pisecco et al, 2001). Generally, research concerning self-concept in children with disabilities show that most children who experience that they have difficulties have a low self-concept. Children with intellectual disabilities for instance often say they can manage to do things they are unable to and this results in failures and disappointment. In the long run this might influence their willingness to try new things e.g. food, activities etc. This will lower their self-concept and they will most suddenly change their attitude and say 'I can't do anything'. The self-concept is of importance in school work as the pupils must trust their ability to manage.

The purpose of this sub-study was to contribute to knowledge about children with ADHD and how these children rated their self-concept. Most studies focus on children's views from parental and teacher perspectives, but in this study the children themselves are in the centre and the informants (Ljusberg \& Brodin, 2007). As appears from research many social, emotional and educational difficulties result in failures in school. The lack of social competence is a huge problem and these children often find themselves in situations they cannot control. The problem occurs immediately and they loose their temper. For their school mates these situations are challenging and many take advantage of it and trig the child with ADHD.

The main interest in this study was to explore if and how training of the working memory affected the children's self-concept and the purpose was to search for knowledge useful for teachers and parents in order to assist these children in school. The data collection involved interviews with parents, researchers and pupils, observations in school and questionnaires. The pupils answered a questionnaire 'This is me' (Taube et al., 1984) and it was used to assess the self-concept from four perspectives: academic, social, personal and global self-concept. Four alternatives to reply were included: YES, yes, NO and no and these were related to the degree of agreement or disagreement. Below are examples of statements in the questionnaire:

The academic self-concept:

I think it is easy to read

I think it is difficult to spell

I need more help from my teacher

I wish I could stop attend school 
The social self-concept

They blame me when it is bully in the classroom

I often play by myself on breaks

The other pupils regard me as stupid

The personal self-concept

I would rather be another child

I like to talk to adults

My parents think I'm OK

The global self-concept included all the above-mentioned statements (Ljusberg \& Brodin, 2007).

The children completed the questionnaire on three occasions - before the training with RoboMemo started, directly after finishing the training period and finally six months after the working memory training. The questionnaire had been tested on a representative sample of all school beginners $(\mathrm{N}=690)$ in 44 regular schools in a town in Sweden and found valid and reliable for the target group (Taube et al., 1984).

The questionnaire 'This is me' was completed in the classroom by the pupils or with assistance of the teacher or assistant, and that is why the result may differ. This was a limitation in the study. The questionnaire had been used by Taube et al. previously and allowed us o compare the mean value $(\mathrm{M})$ on all three scales as well as the global scale. Taube reported one occasion of measurement while the BASTA involved three (Ljusberg \& Brodin, 2007). However, we do not have access to the standard deviances in the comparison data. The dominating pattern was that the differences were small to nonexistent between the BASTA data and the comparison data concerning global, academic, social and personal selfconcept. Few changes are visible in the material with regard to the self-concept of the children. We know however that RoboMemo improved the working memory capacity and this resulted in a higher capacity of the skills in reading, writing and mathematics. The increased academic skills might have affected the self-concept in the long run as a higher intellectual skill often influences the self-confidence and the self-esteem. Remarkable was that the children reported a higher degree of self-concept than expected although most people think that entering a remedial class is in a way linked to academic and social failures.

The main question is to find out what these children learn in school as the main task in school is learning in a wide perspective. The children said they had a good self-concept but it appears from the questionnaire that they overestimated their self-concept. That they reported a higher self-concept than expected may confirm the theory of protection. Some researchers mean that the inflated self-concept serve a self-protective role for children with ADHD despite experiences of failure. Awareness of this may facilitate for the teachers. In other words: Boys with ADHD can relax their self-protective position once they know it is not needed and from a pedagogical point of view this is an interesting finding. As Ljusberg (2009) expressed it: 'they can lower their guards'. The main result was that despite repeated failures children showed a fairly good self-concept. However, they still need positive support from persons in the immediate environment to succeed in school work and in school the key persons are the teachers. In the next section teacher education and teaching will thus be in focus.

\section{Teaching children with ADHD}

Teaching in today's school is demanding and challenging and many teachers state that they experience difficult teaching situations with too many pupils in the class and a shortage of 
special education knowledge. An observation is that many teachers leave their jobs shortly after having finished their teacher training as the job was not what they expected it too be. It is too demanding and they state that they don't feel that they have knowledge enough to work with children in need of special support. The weak connection between theory and practice is especially criticized and the shortage of special solutions to classroom problems combined with the fact that children in many schools have complex needs and mental health problems are realities that have not been stressed strongly enough in teacher training (Brodin, 2011). Another aspect is that inclusion demands both careful teacher training and time to make changes (Brodin \& Lindstrand, 2007). Inclusion is expected to give equal opportunities and participation for all children but the number of remedial classes is ever increasing. This is especially true for children with neuro-psychiatric disorders, who often have difficulties to take part in education in a regular class.

For children who have ADHD the school day is often problematic as they lack social competence (Barkley, 2006). They are often involved in conflicts with peers and teachers and they are regarded as bully and disturbing. Their difficulties to concentrate often result in inattentiveness and when the teachers give instructions to the class their thoughts are often somewhere else. They miss a lot of information and when other pupils listen to the instruction and start to work on the task these children have lost the whole message (Brodin \& Ljusberg, 2008; Hellström, 2010). They have not understood the task and they cannot catch up as they have not 'heard' the instructions. Besides it is impossible for these pupils to remember long instructions from the teacher as they have limitations in the working memory capacity. This is why it is important to train the capacity of the working memory. The main problem for these children is that they feel stupid and are anxious to ask the teacher to repeat the instruction again. Instead they choose to skip the task without giving any reason, which of course is the easiest way to get away from the tiring situation. If the teacher divides the instructions in smaller sequences it would be a great help to these children. The teacher must realize that these children have many difficulties partly due to the large number of failures they have earlier experienced in school.

The interviewed children were fully aware why they attended the remedial class. One problem in school is that children with ADHD influence their classmates' opportunities to concentrate and learn due to their misbehaviour and they hinder the teachers to teach effectively. The rules recommended by Gillberg (2005) i.e. small teaching groups or remedial classes, individual instructions in reading, writing and mathematics, short sequences for concentration and a number of physical activities, are still very useful. Structure and routines will benefit all children. Another aspect is that the tasks in school must be of interest for the pupils and it is for many teachers challenging to find tasks for all.

The purpose of this study was to increase the teachers' and parents' knowledge of the school situation for children with ADHD and data were collected by a questionnaire to the teachers $(\mathrm{N}=21)$ and parents $(\mathrm{N}=40)$. One parent dropped out. The classes were mixed with pupils of different ages and 24 pupils had attended the class for less than three semesters. A majority of the children participated in activities organized together with the pupils from the regular classes, which means that the school and teachers have tried to meet the goals of inclusion. The teachers mentioned that short breaks, gymnastics, lunch breaks and outdoor education were the most common activities they spent together. Many pupils with ADHD or similar symptoms had inferior skills and produced academic results that left them at the bottom of the class. 
Most teachers worked full time in the remedial class and half of them had been working in the class between one and three semesters, which is a short time. This is definitely not benefiting these pupils. It was evident that these children had to change teachers often. Many teachers were rather old and had an old basic teacher training and that is a wellknown fact from other European countries. Old teachers do not necessarily mean that they are poor teachers but they have an old education and when they were in teacher training few talked about children with neuro-psychiatric disorders. Another problem is that many schools also had difficulties to recruit teachers. A majority of the parents $(\mathrm{N}=34)$ expressed that they were satisfied with the school situation of their child and they did not have any complaints about it. Some were also satisfied that their child had been moved to the remedial class as they believed that the child would now get all the support he or she needed. The parents said that they were relieved when the disorder of the child was confirmed.

This reminds me on the situation for children with intellectual disabilities in Sweden long time ago. When they were placed in institutions the parents expected them to get the very best education and help but many years later they realized that their children had just been placed at an institution without the expected support.

A majority of the teachers in the BASTA project had received their teacher education during the 1960s and 1970s. None had experience of special education. Seven of them had taken courses and got in-service training and they regarded themselves as competent for the job and added that 'I get enough experience in the classroom'. The teachers experienced a tough time working with these pupils and only half of them stated that they got supervision. The parents reported that they relied completely on the teachers' skills. Most of the teachers had extra staff in the classroom to support the pupils and thus felt satisfied. The parents were sure that their son or daughter had good support. Some parents however pointed out that educated young teachers ought to be recruited, as they would have more energy to work with these restless and trying children. With regard to the staff turnover and stability in the class both teachers and parents seemed to be satisfied and the teachers pointed out that they found the classroom climate better in the remedial class than in the regular classes. The teachers said that 'for these children the remedial classes are the best solution'.

The teachers highlighted the difficulties they had to teach in the remedial class as the pupils are disorderly, restless, hyperactive and inattentive. Many of the pupils could only concentrate a couple of minutes at each time and then started to move around in the classroom. Much time was spent on correction of the pupils' unacceptable behaviour, and to make them listen to their instructions instead of teaching.

Despite that these children had been placed behind screens and work for themselves without distraction and interruption from others, they disturbed each other by throwing paper balls or rubbers at their peers. These disturbances of course also existed in regular classes and in other educational contexts. As their span of attention is extremely low they are distracted by other activities going on and easily lose the red thread. Barkley $(2002,2006)$ states that these children as soon as they get an opportunity do what they found most tempting for the moment. The situation would probably not be better in a regular class.

The question is why parents are so satisfied with the placement in the remedial class. At least two explanations are visible. First of all they believe that their child will get a lot of help and they do not need to worry about the child's education, secondly that they avoid to 
get complaints about their child's behaviour from the school as the child's behaviour is more or less accepted in the remedial class. Another explanation is that the parents realize that despite the teachers' lack of special education, complaints will not help. When the child is placed in a remedial class the parents can relax instead of worrying about the behaviour of their child. Also the teachers and school staff seem to be satisfied with the situation which seems strange. How can they feel satisfied when they cannot teach as they want to? Why don't they ask the headmaster for more resources if they cannot do their job in a way good enough?

We know that the great number of academic and social failures has contributed to a low self-concept and confidence in children with neuro-psychiatric disorders. But how are these pupils treated in school? What are they expected to learn in school and what are they actually learning? Ljusberg (2009) was very provocative when she said that what these children primarily learn 'is to be pupils in a remedial class' (p. 51). The teachers often stressed that they train the children to behave nicely in order to be transferred to a regular class in the future - but how often does this happen? Few pupils have been and will go back to the regular class and in the meantime they loose a lot of opportunities to learn. 'A relevant question is if these children learn more in a remedial class than in a regular class, or if the small class is chosen as en emergency solution for the teachers only?' (Brodin \& Ljusberg, 2008, p. 354). Evidently the pupil is bearer of the school's problem (Karlsson, 2008).

\section{Interviewing children with ADHD and ethical aspects}

Children constitute an overexposed group in research because they are under age and because they are in a dependent relationship with adults. What can we learn from interviews with children with ADHD in remedial classes - what do they want to tell us? This sub-study was conducted with ten children between ten and twelve years of age, who were attending ten different remedial classes. The aim was to stress how children with neuro-psychiatric disorder described themselves and why they were attending the class, as most of these children actually wanted to attend a regular class. Semi-structured interviews formed the basis and the results showed that the children 'are carriers of their schools compensatory perspective' (Ljusberg, 2010). These children know that they are regarded as difficult, annoying and problematic and they know that they are moved to the remedial class because they were so problematic in the regular class that the teacher could not manage. They are fully aware of their situation and confirm that they have difficulties, are restless and inattentive and they blame themselves. These young children are between ten and twelve years old and they take over the whole responsibility for the placement. Ljusberg (2009) states that it is the remedial class per se that creates social difficulties for these children. When working with the interview study we noticed that there are many ethical issues coming up which we had not regarded carefully enough (Ljusberg, Brodin \& Lindstrand, 2007). The main reason for highlighting ethical issues in child and childhood research is to protect the involved children and to avoid negative consequences from participation in the project. Ethical issues in child studies are an area that must be stressed more often and in a broader perspective.

Lately, research concerning children's perspectives has increased. Children are under age, they are used that adults talk about them and over their heads and often their opinions have minor influence (UN, 1989). Normally the child possesses information that the researcher wants, i.e. the child's thoughts and opinions, and the ambition was to listen to their voices. One ethical issue is why we build up a school with remedial classes and segregate children 
who are not good enough. These children are often regarded as troublemakers and few evaluations have been done in remedial classes (Ljungberg, 2001; Teeter, 2004). Earlier interventions on children with ADHD in classroom settings have shown minor improvements in academic skills and behaviour (Tannock \& Martinussen, 2001), so we cannot argue that we make life easier for these children by placing them in a special class. The ethical issue concerns how we can defend this conscious exclusion when we are talking about inclusion and a school for all. Two controversy pictures of reality.

Before children are involved in research a written permission of the parents is needed but the child also needs to accept the conditions for being interviewed. When children are involved it is also important that there are no bonds or relationships of dependency between the researcher and the child. The risk of identification is always a problem when working with children in difficult situations and we therefore tried to hide data that could be identified by making summaries. Some of the children felt special as they were selected to participate and sometimes gave information that they would probably not do otherwise, and this might be a dilemma. Being a child in a remedial class implies exclusion from ordinary teaching.

One boy (10 years old) told us about his special situation and the anger and distress he felt. He blamed his mother for being placed in the remedial class and also mentioned other things that irritated him about the mother. Suddenly he said that he should write a letter to his mother and tell her that he had moved from home. The interviewer then said that the best he could do was to tell his mother that he was angry with her. The boy replied that he felt that his father cared more about him than his mother (Ljusberg, et al., 2007, p. 207).

The conversation went on and the boy had used the interviewer to test his ideas. After that the interview continued as normal. This boy really expressed his dissatisfaction with being a pupil in a remedial class but he had problems to talk about it with his parents. Sometimes children give sensitive information; later they might feel that they have gossiped about someone. The researcher often receives confidential information and must take responsibility for how it is used, but without being a therapist. The most important is to listen to children's voices and to create learning environments in school where all children feel welcome and good enough from their prerequisites (Brodin, 2011; Danby \& Farrell, 2004). Equal opportunities and participation is an ethical issue.

\section{The school setting}

To summarize, the difficulties for children with ADHD in everyday life primarily concern domains such as education, social relations, self-esteem, self-concept, family functioning and independence. The school is an arena attended by all children and learning is the most important task in school (Brodin \& Lindstrand, 2007; Brodin \& Ljusberg, 2007). The function we use to store information is the working memory and this function is central for attention and concentration on a task but also to control impulses. The working memory is thus vital for learning and problem-solving as it helps us to remember what we are going to do next which is important in school work. It works when the child is reading and writing, for mathematics and these skills affect their academic achievements. Ljungberg (2001) suggested that ADHD can develop differently depending on the social environment and due to this the school setting is of great importance. Based on reported research I support the combination of medical, social and educational factors. 
In today's society we are flooded with information and to handle this information we need to coordinate and interpret what we see and hear. Our brain needs to be able to judge whether the information is valuable or not. Many brain functions can be compared to computerized calculations, e.g. memory, selection of information and working memory. The function of the working memory is to keep information actual in the brain and this function is developed during the first years of life. Memories of facts and actions will be stored in the working memory while they are coded into the long term memory. For children with neuropsychiatric disorders training of the working memory capacity is decisive for their learning (Westberg, 2004).

Our observations in the classroom showed that the pupils commonly were placed one by one with the desk placed against a wall. Between the pupils a screen was placed in order to avoid distraction of other children. The main reason for this was to do the best for the children as they are inattentive and easily loose their interest for a task. There are small talk going on between the teacher and the pupils and the climate in the classroom seemed to be calm and friendly. The teachers' ideas are to compensate for the disorder and they explain that their role is to meet every child where he/she is (Brodin \& Ljusberg, 2008; Teeter, 2004). The teachers in the remedial class talk in a critical way about the teachers working in the regular school. They also state that pupils with ADHD have problems the school cannot solve. When looking at the so called classroom - it is easy to understand that visitors in the class must question the placement of the pupils. The organization of the classroom is of great importance and it shows obvious what expectations the teachers have on their pupils. Hellström (2004) talks about 'self-fulfilling prophecy' and many of these children follow the pattern expected from them. One of the main questions is how interaction between the classmates works. They say that they have minor social exchange outside school and at breaks during the school day. Is a hard structure of the classroom a good solution from an educational point of view or can the school setting better be adapted to fit all children in the class? Probably not! The strict structure in the classroom just confirms and conserves the deviant behaviour in the school setting. How much of individual teaching is needed to stimulate their interests for learning? The main task for the school must be education and to give pupils positive educational and relational experiences that will make life easier for them.

\section{Social and educational implications of ADHD in school}

In the western world we can today note an increase of children with difficulties in managing and adapting in the regular school and many children with neuro-psychiatric disorders will in the long run drop out of school. This situation is not acceptable from the child's perspective. They have the right to learn and they must be given equal opportunities in the same way as other children of their age. These children cause a huge problem for the teachers who often lack knowledge of special education related to this disorder (Brodin \& Ljusberg, 2008) and based on this Teeter (2004) recommends that intervention based on reliable tests should be done. In many countries children with ADHD are transferred to remedial classes and segregated from their classmates in regular classes and many researchers are sceptical to this solution (e.g., Ljusberg, 2009). They state that many pupils presumed at risk when they start school are seen in the same way during their entire school careers which means that they are labelled for life. This is also what many parents are afraid of. Some parents mean that ADHD is a negative label and they sometimes reject to see the difficulties in the child as they do not want to have their child labelled. But this is a mistake 
as the child cannot get the help he/she needs. The question is when 'the best of the child' is stated in the UN Convention (1989) - what does it really mean? Whose interest is in focus? The parents might feel responsible for the child's behaviour but hope that the complicated situations and difficulties will disappear when the child gets older. In the meantime these children feel misunderstood and that they do not fit in. The well-being of the child is set aside (Brodin, 2011). The choice for these children is to be segregated and placed in a remedial class for children with ADHD which is located in a regular school. The placement in remedial classes has negative consequences with regard to inclusion and many researchers (e.g., Karlsson, 2008; Skidmore, 2004) argue that there is no support for the superiority of remedial classes. But in Sweden the number of special classes for children with different disorders is increasing. The discrepancy between political goals (an inclusive school) and reality (special solutions) is a fact. At the same time we get reports that many school-age children feel misunderstood are unhappy and do not feel well in the Swedish school.

\section{Communication and social interaction}

Although the main task in school is learning basic academic skills such us reading, writing and mathematics also other goals e.g. communication and social interaction are vital. Children with ADHD often have difficulties in communication and social interaction and many children experience a problematic school day as they lack social competence to interact with their schoolmates and their teachers (Barkley, 2006; DuPaul \& White, 2006; Kadesjö, 2010). This mainly depends on their difficulties in listening to people around, e.g. to the teacher's instructions and to finish a task in school (Westerberg, 2004). They get easily involved in conflicts with peers as they have difficulties to adapt to approved social rules and to control their impulses. In order to find a way out, they get involved in a fight. Children who cannot express themselves use the fists to convince the peers. As a whole these children are regarded as bully and disturbing by peers and teachers (Brodin \& Ljusberg, 2008), and interviews with these children showed that they blame themselves for being placed in the remedial class. 'It is my fault - I can't behave - I'm bully'. They often have failed to build up relations with peers both inside and outside of school and many of these children feel very lonely since they have been moved to the remedial class. They have lost many of their friends and they have difficulties in building up new relations. In a way they have a realistic self-concept because they repeat all the time that they are problematic and that the other schoolmates tease them and call them 'DAMP-children'. There are many negative aspects with ADHD but there are also positive aspects. Many of these children are seen as exciting and challenging as they dare to break rules and follow their instincts. A lot of exciting but sometimes dangerous things happen around them. Their thinking is often unconventional and they are extremely brave to try new activities as they do not consider the consequences. They are also extremely concentrated on things they really found interesting. Often we hear about children who have learnt things that have no real meaning for most of us. The challenging issue for the teacher is to find out exactly what interests each child has. All children are unique and differences between children are challenging but stimulating. If they all were the same nothing exciting would happen in life.

\section{What can we do to help these children to lead a good life?}

Children with ADHD have equal rights to education as all children. Most of the research today highlights the problems with these children and this article also confirms that there 
are huge problems in school. Most countries are working towards an inclusive school, but in spite of that most countries segregate these children and place them in special classes. The reason is that they are too bully and disturbing for their classmates and for the teacher. The teachers often complain about the difficult classroom situation and the lack of moments of 'possible teaching'. The main question is what we can do to facilitate education and learning for these children?

Many aspects influence learning for instance the teacher training, the teacher's view of the child, the parent's acceptance of the child's disability, the learning material in school, the school tasks, and the school setting including the structure of the classroom.

The teacher training is crucial. The teachers need more knowledge of special education in their regular teacher training. They must be trained to work with all children, despite difficulties and prerequisites and they also must be trained to meet the needs of children with different backgrounds and disabilities with respect. This is partly an educational aspect, partly a human aspect i.e. how they view the children with ADHD, what prejudices they carry. Hellström (2004) talks about full-filling prophesy and it is dangerous if the teacher already from the start have an idea of the functioning of each child. To label children for life creates a problem - they need a second chance. If the school supported all children based on their special needs this would probably be the best for each child (typical or atypical). Flexibility is a word that should be highlighted more often. Structure and routines are also useful concepts to support all children. Consequently, teachers need a better basic training and they need at least a little knowledge about how the brain develops in a young child in order to have realistic expectations on the child's learning opportunities. The tasks must be of interest for the child and this is a major problem also in the regular school. The school is sometimes very old-fashioned and the norms of the school are difficult to understand for today's children. We live in the digital age and many teachers are not updated on how much influence ICT has on children's world. Children are always children of his or her time.

Today there are also a large number of programmes for behaviour modification available on the market. Teachers need training in how these programmes can be used to change the behaviour of the child. The main principle of modification is to reinforce and praise all activities and behaviour that is approved and nice and to neglect misbehaviour. Some schools are working with token economy which means that a good behaviour renders some kind of reward. This will often stimulate the child to modify his or her bad behaviour.

Also the parents need knowledge of ADHD and what implications it has on the child's daily life. In many countries special parent education is organized where the parents of a child with disorder can meet other parents with the same interests (Chandler, 2010). Intervention must always involve the child's entire situation both at home and at school and the methods used for treatment should be evidence-based in order to be successful. Normally the treatment starts with changes in the immediate environment, i.e. to adapt the school setting to fit the needs of the child. Sometimes this is not enough and medication is used as a complement. Intervention and treatment of children with ADHD in school are constantly on the agenda and a highly discussed topic in media. A small group of medical doctors reject to prescribe Ritalin or similar medication to children while most neuro-psychiatric doctors see it as a complement to environmental aspects (Eriksson \& Ingvar, 2004).

As mentioned above special training programmes might help the child to perform better. One example is the RoboMemo programme for training of the working memory capacity 
(Klingberg, et al., 2005) that has been of great help for many children concerning basic academic skills. In the long run it is reasonable to believe that a child who performs better in school also gets a changed and stronger self-concept. There are also a quite large number of pedagogical methods used today and the development of new ways to treat these children is constantly on its way. The tasks in school and the material used must sometimes be changed and developed and the teachers must often use their fantasy to find solutions. Teachers and parents must cooperate in order to strengthen the confidence in these children, and structure and routines will contribute to their well-being (Brodin, 2011).

Finally, the school setting is of importance. The classroom is structured to help the child, but if the remedial class is only an occasional placement, then it will be difficult to go back to the regular class as the immediate environment will look so different. The feeling when coming into a class with no natural social interaction between the pupils is strange. If they want contact they just throw away a rubber or a piece of paper on somebody, who immediately reacts with anger. Perhaps a negative contact is better than no contact at all for these children. As many of these pupils are hyperactive the structure is a way to keep the atmosphere nice and calm in the classroom. The interviews with the children with ADHD showed that 'the school focused on the pupil's shortcomings instead of the pupil in the context' (Ljusberg, 2009, p 47).

Still research from a pedagogical aspect is limited and more research should be conducted in order to better meet the needs of these children. Some aspects seem more important than others; high teacher density, qualified teachers, small classes and few pupils, short and clear instructions, many breaks, adapted tasks, cooperation between parents and teachers, intervention and suitable treatment, e.g. to use evidence-based pedagogical programmes for behaviour modification. Besides, respect for the child, to do the best for the child, to listen to the voice of the child, and to invite the child to have influence on the teaching and whole school setting are important aspects to facilitate daily lives of these children.

\section{References}

Alin åkerman, B. (2008). Psykisk ohälsa och risk för självmordshandlingar bland ungdomar [Mental unhealth and risk for suicide among youngsters].In J. Brodin (Ed.) Barn i utsatta livssituationer [Children in exposed living situations] (pp. 133-170). Malmö: Gleerup. Education.

Brodin, J. (1997). Självuppfattning hos personer med intellektuella funktionshinder. [Selfconcept in children with intellectual disabilities] TKH-report 15. Stockholm: Stockholm Institute of Education.

Brodin, J. (2008). Barn med funktionsnedsättningar [Children with disabilities]. In J. Brodin [Ed.) Barn i utsatta livssituationer [Children in exposed living situations]. Malmö: Gleerup.

Brodin, J. (1997). Självuppfattning hos personer med intellektuella funktionshinder. [Selfconcept in children with intellectual disabilities] TKH-report 15. Stockholm: Stockholm Institute of Education.

Brodin, J. (2009). Support systems in preschool and school for children with disabilities, IRIS (Improvement through Research in the Inclusive School), EU project. www.irisproject.eu

Brodin, J. (2011). Children in precarious environments and life situations. International Journal of Child and Adolescent Health 4(2), 131-138. 
Brodin, J.\& Lindstrand, P. (2007). Perspectives of a school for all. International Journal of Inclusive Education, 11(2), 133-145.

Brodin, J. \& Ljusberg, A-L. (2008). Teaching children with attention deficit hyperactivity disorder in remedial classes. International Journal of Rehabilitation Research, 31(4), 351-355.

Barkley, R. A. (1997). ADHD and the nature of self-control. New York: Guilford.

Barkley, R. A. (2002) (Ed.). International Consensus Report on ADHD. University of Massachusetts Medical School: Dept. of Psychiatry and Neurology.

Barkley, R. A. (2006). Attention Deficit - Hyperactivity Disorder: A handbook for diagnosis and treatment (3rd ed.) New York: Guilford.

Beckman, V. \& Fernell, E. (2004). Utredning och diagnostik [Intervention and diagnostic]. In v. Beckman (Ed.) ADHD/DAMP - en uppdatering [ADHD/DAMP - updated]. (pp 21-35). Lund: Studentlitteratur.

Chandler, C. (2010). The science of ADHD: A guide for parents and professionals. Malden, MA: Wiley-Blackwell.

Danby, S. \& Farrell, A. (2004). Accounting for young children's competence in educational research: new perspectives on research ethics. The Australian Educational Researcher, 31(4), 35-49.

Diagnostic and Statistical Manual of Mental Disorders DSM-IV, rev. 2002. NY: American Psychological Association (APA).

DuPaul, G. J. \& White, G. P. (2006). ADHD: Behavioral, Educational and Medication Interventions. Education Digest, 71(3), 57-60.

Eriksson, E. \& Ingvar, M. (2004). About ADHD: an actual fight going on in Sweden. In v. Beckman (Ed.) ADHD/DAMP - en uppdatering [ADHD/DAMP - updated]. (pp 123132). Lund: Studentlitteratur.

Gillberg, C. (2005) (2nd. ed.). Ett barn i varje klass. Om DAMP, MBD, ADHD [One child in each class. On DAMP, MBD, ADHD]. Stockholm: Cura.

Harwood, V. (2006). Diagnosing 'Disorderly' Children. A critique of behaviour disorder discourses. London: Routledge.

Hellström, A. (2004). Psykosociala och pedagogiska stödinsatser [Psychosocial and pedagogical interventions. In. V. Beckman (Ed.) ADHD/DAMP - en uppdatering [ADHD/DAMP - updated]. (pp 101-122). Lund: Studentlitteratur.

Hellström, A. (2010). Att vara förälder till ett barn med ADHD - så kan du underlätta vardagen [To be parents of a child with ADHD - how to facilitate everyday life]. Stockholm: ADHD-centre.

Hoza, B., Pelham, WE. Jr., Dobbs, J., Owens, J., \& Pillow DR. (2002). Do boys with attentiondeficit/hyperactivity disorder have positive illusory self-concepts? Journal of Abnorm Psychology 111, 268-278.

Ingvar, M. (2004). Uppmärksamheten och hjärnan [Attention and the brain]. In V. Beckman (Ed.) ADHD/DAMP - en uppdatering [ADHD/DAMP - updating] (pp 35-47). Lund: Studentlitteratur.

Kadesjö, B. (2008). Barn med koncentrationssvårigheter [Children with concentration difficulties]. Stockholm: Liber.

Kadesjö, B. (2010). Barn som utmanar - Barn med ADHD och andra beteendeproblem [Challenging children - Children with ADHD and other behaviour problems]. Stockholm: The National Social Board of Helth and Welfare. Electronic resource.

Karlsson, Y. (2008). Att inte vilja vara ett problem - social organisering och utvärdering av elever $i$ en särskild undervisningsgrupp [Resisting problems - social organisation and evaluation practices in a special teaching group]. Linköping: Linköping University. Dissertation. 
Klingberg, T., Fernell, E., Olesen, P., Johnson, M., Gustavsson, P., Dahlström, K., Gillberg, C., Forssberg, H. \& Westerberg, H. (2005). Computerized training of working memory in children with Attention.Deficit/Hyperactivity Disorder - A randomized, controlled trial. Journal of the American Academy of Child and Adolescent Psychiatry, 44(2), 177-186.

Landin, I. (2007). RoboMemo - en utvärdering av arbetsminnesträning för barn med ADHD [RoboMemo - an evaluation of working memory training for children with ADHD]. Report 8/2007. Malmö: Dept. of Research and Development, www.skane.se/habilitering/fou

Ljungberg, T. (2001). ADHD hos barn och ungdomar - Diagnostik, orsaker och farmakologisk behandling. [ADHD in children and youngsters - Diagnostics, causes and pharmacological treatment]. Stockholm: The Social Board of Health and Welfare.

Ljusberg, A-L. \& Brodin, J. (2007). Self-concept in children with attention deficits. International Journal of Rehabilitation Research, 30(3), 195-201.

Ljusberg, A-L. (2009). Pupils in remedial classes. Stockholm University: Department of Child and Youth studies. Dissertation.

Ljusberg, A-L. (2011). Children's views on attending a remedial class - because of concentration difficulties. Child: care, health and development. iFirst 2011, 1-6.

Ljusberg, A-L. \& Brodin, J. (2007). Self-concept in children with attention deficits. International Journal of Rehabilitation Research, 30(3), 195-201.

Ljusberg, A-L. \& Brodin, J. \& Lindstrand, P. (2007). Ethical issues when interviewing children in remedial classes. International Journal of Rehabilitation Research, 30(3), 203-207.

Lloyd, G. (2006). Conclusion: Supporting children in School. In G. Lloyd, J Stead \& D. Cohen (Eds.) Critical new perspectives on ADHD, (pp 215-228) London: Routledge Falmer.

Matson, I-L. (2007) En skola för eller med alla [A school for or with all children]. Stockholm: Stockholm Institute of Education. Licentiate Dissertation.

Nirje, B. (2003). Normaliseringsprincipen [The Normalization Principle]. Lund: Studentlitteratur.

Norwich, B. (2008). Dilemmas of difference, inclusion and disability. International perspectives and future directions. London: Routledge, Taylor \& Francis group.

Pisecco, S., Wristers, PS., Silva, PA., Baker, DB. (2001). The effect of academic self-concept on ADHD and antisocial behaviours in early adolescence. Journal of Learning Disability, 34, 450-461.

Salamanca Statement (2001). Stockholm: The Swedish Board of Unesco.

Socialstyrelsen [The National Board of Health and Welfare] (2004). Kort om ADHD hos barn och vuxna: en sammanfattning av socialstyrelsens kunskapsöversikt [Brief on ADHD in children and adults: a summary and literature review]. Stockholm: The National Board of Health and Welfare.

Skidmore, D. (2004). Inclusion - the dynamic of school development. Maidenhead: Open University Press.

Tannock, R. \& Martinussen, R. (2001). Reconceptualization ADHD: Educ. Leadership, 59, 20-26.

Taube, K., Torneus, M. \& Lundberg, I. (1984). Umesol, Självbild [Umesol - self-concept] Stockholm: Psychology Press.

Teeter, P. A. (2004). Behandling av ADHD - ett utvecklingspsykologiskt perspektiv [Treatment of ADHD - a developmental pschychological perspective]. Lund: Studentlitteratur.

UN Convention on the Rights of the Child (1989). New York: United Nations.

Wells, KC. (2004). Treatment of ADHD in children and adolescents. In PM Barrett and TH Olledick (Eds.) Handbook of interventions that work with children and adolescents: Prevention and treatment. Chichester, UK: John Wiley. Pp. 343-368.

Westerberg, H. (2005). Working Memory: Development, Disorders and Training. Stockholm: Karolinska Institute. Dissertation. 


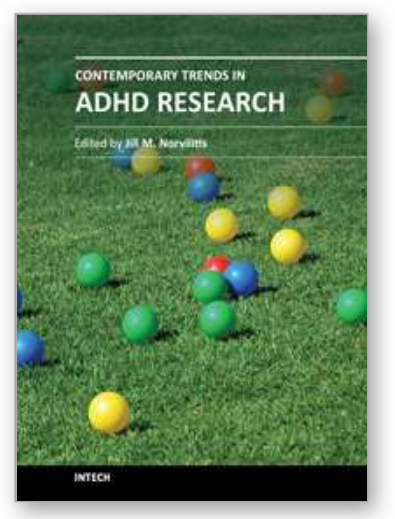

\section{Contemporary Trends in ADHD Research}

Edited by Dr. Jill M. Norvilitis

ISBN 978-953-307-858-8

Hard cover, 196 pages

Publisher InTech

Published online 15, February, 2012

Published in print edition February, 2012

With many children and adults affected by Attention Deficit Hyperactivity Disorder, researchers strive to understand the underpinnings of ADHD and associated factors on both a basic and applied level. The goal of this volume is to explore some of the broad array of research in the field of ADHD. The 12 chapters cover a variety of topics as varied as postural control, endocrine dysfunction, juvenile justice, and academic outcomes. These chapters will provide valuable insights for students reading about ADHD for the first time, researchers wishing to learn about the latest advances, and practitioners seeking new insight in the field.

\section{How to reference}

In order to correctly reference this scholarly work, feel free to copy and paste the following:

Jane Brodin (2012). Remedial Education for Children with ADHD in Sweden, Contemporary Trends in ADHD Research, Dr. Jill M. Norvilitis (Ed.), ISBN: 978-953-307-858-8, InTech, Available from:

http://www.intechopen.com/books/contemporary-trends-in-adhd-research/remedial-education-for-childrenwith-adhd-in-sweden-

\section{INTECH}

open science | open minds

\section{InTech Europe}

University Campus STeP Ri

Slavka Krautzeka 83/A

51000 Rijeka, Croatia

Phone: +385 (51) 770447

Fax: +385 (51) 686166

www.intechopen.com

\section{InTech China}

Unit 405, Office Block, Hotel Equatorial Shanghai

No.65, Yan An Road (West), Shanghai, 200040, China

中国上海市延安西路65号上海国际贵都大饭店办公楼 405 单元

Phone: +86-21-62489820

Fax: +86-21-62489821 
(C) 2012 The Author(s). Licensee IntechOpen. This is an open access article distributed under the terms of the Creative Commons Attribution 3.0 License, which permits unrestricted use, distribution, and reproduction in any medium, provided the original work is properly cited. 